\title{
Universiteit
}

Leiden

The Netherlands

\section{The Death of the Democratisation of the Afterlife}

Hays, H.M.; Strudwick N., Strudwick H.

\section{Citation}

Hays, H. M. (2011). The Death of the Democratisation of the Afterlife. Old Kingdom: New Perspectives. Egyptian Art And Archaeology 2750-2150 Bc, 115-130. Retrieved from https://hdl.handle.net/1887/18322

Version: $\quad$ Not Applicable (or Unknown)

License: $\quad$ Leiden University Non-exclusive license

Downloaded from: https://hdl.handle.net/1887/18322

Note: To cite this publication please use the final published version (if applicable). 


\title{
The death of the Democratisation of the Afterlife
}

\author{
Harold M. Hays
}

So much has been written against the theory of the democratisation of the afterlife that it may be deemed obsolete. Even two encyclopaedia entries have been prepared which survey the major objections against it, definitively declaring that the events which it supposes did not take place. ${ }^{1}$ This development speaks to just how acceptable its refutation should be by now. Challenges to the theory began appearing in earnest a decade and a half ago, ${ }^{2}$ spurred on in part

1 See M. Smith, 'Democratization of the Afterlife', in J. Dieleman and W. Wendrich (eds), UCLA Encyclopedia of Egyptology, (Los Angeles 2009, http://repositories.cdlib.org/nelc/uee/1147, accessed 5/6/2009), and H. Willems, 'Die Frage der sogenannten "Demokratisierung des Jenseitsglaubens" vom späten Alten Reich bis zur Zweiten Zwischenzeit', to appear in J. Assmann, H. Roeder (eds), Handbuch der altägyptischen Religion (Handbuch der Orientalistik; Leiden forthcoming). I heartily thank the latter for graciously providing me with a draft copy of this crucial work.

2 P. Jürgens, Grundlinien einer Überlieferungsgeschichte der altägyptischen Sargtexte (GÖF IV. Reihe Ägypten 31; Wiesbaden 1995), 86; D. P. Silverman, 'The Nature of Egyptian Kingship', in D. O'Connor and D. P. Silverman (eds), Ancient Egyptian Kingship (PdÄ 9; Leiden 1995), 80-82; id., 'Coffin Texts from Bersheh, Kom el Hisn, and Mendes', in H. Willems (ed.), The World of the Coffin Texts (Leiden 1996), 140-141; K. Nordh, Aspects of Ancient Egyptian Curses and Blessings (Uppsala 1996), 168-172; B. Mathieu, 'Que sont les Textes des Pyramides?', Égypte Afrique et Orient 12 (1999) 20; id., 'La distinction entre Textes des Pyramides et Textes des Sarcophages estelle légitime?', in S. Bickel, B. Mathieu (eds), D'un monde à l'autre. Textes des Pyramides et Textes des Sarcophages (BdE 139; Cairo 2004), 256-258; H. Willems, Les Textes des Sarcophages et la démocratie (Paris 2008), 131-228. Earlier critiques of the theory had already been made in R.E. Briggs, 'Excursus VII: Astronomy in the Pyramid Texts', in S.A. B. Mercer, The Pyramid Texts in Translation and Commentary IV: Excursuses (London 1952), 43, and J. Bourriau, Pharaohs and Mortals. Egyptian Art in the Middle Kingdom (Cambridge 1988), 83 and cf 86. On non-royal access to religious rituals and beliefs in the Old Kingdom, see also J. Baines, 'Restricted Knowledge, Hierarchy, and Decorum: Modern Perceptions and Ancient Institutions', JARCE 27 (1990), 11 n. 60; H. Altenmüller, 'Der Grabherr des Alten Reiches in seinem Palast des Jenseits: Bemerkungen zur sog. Prunkscheintür des Alten Reiches', in C. Berger el-Naggar and B. Mathieu (eds), Etudes sur by the discovery of religious texts from the Balat coffin of the official Medunefer, ${ }^{3}$ datable to the reign of Pepy II. ${ }^{4}$ As these have not been addressed by a proponent of the old theory, it should be safe to say that current scholarly opinion sees the theory as quite dead.

My personal experience has been otherwise. When I spoke against the democratisation theory at the Old Kingdom Art and Archaeology congress in 2009, many of the participants seemed rather shocked, and it continues to be taken for granted elsewhere. ${ }^{5}$ The reaction which

l'Ancien Empire et la nécropole de Saqqâra dédiées à Jean-Philippe Lauer I (Montpellier 1997), 16-17; H. Altenmüller, 'Der Himmelsaufstieg des Grabherrn-Zu den Szenen des žš ws $\underline{\text { d }}$ in den Gräbern des Alten Reiches', SAK 30 (2002), 36; N. Alexanian, 'Himmelstreppen und Himmelsaufstieg. Zur Interpretation von Ritualen auf Grabdächern im Alten Reich', in H. Guksch, E. Hofmann and M. Bommas (eds), Grab und Totenkult im Alten Ägypten (Munich 2003), 35-38.

3 Jürgens, Grundlinien, 86; Silverman in O'Connor and Silverman (eds), Ancient Egyptian Kingship, 80; Nordh, Aspects, 174; and Mathieu, in Bickel and Mathieu (eds), D'un monde à l'autre, 254. cf D.P. Silverman, 'Textual Criticism in the Coffin Texts', in J.P. Allen et al., Religion and Philosophy in Ancient Egypt (YES 3; New Haven 1989), 36. For the texts, see M. Valloggia, Balat I. Le mastaba de Medou-Nefer, Fasc. I (FIFAO 31.1; Cairo 1986), 75-76. See also L. Gestermann, 'Sargtext aus Dair al-Biršā. Zeugnisse eines historischen Wendepunktes?', in Bickel and Mathieu (eds), D'un monde à l'autre, 210-211 with n. 39, where the ambiguity of identification for the extremely fragmentary remains is highlighted. The excavations at Tabbet al-Guesh yielded a non-royal wooden coffin with religious texts that may turn out to be dated to the reign of Pepy I, according to the presentation of V. Dobrev, 'Old Kingdom "Houses of Eternity" and Late Period "Mastabas" at Tabbet al-Guesh (South Saqqara)', given at the congress 'Abusir and Saqqara in the Year 2010' in Prague 2010.

4 As there are items from his tomb naming Pepy II (Valloggia, Balat I, 167-170). A further tomb with religious texts, that of Meni at Dendera (D1D), is sometimes dated to the Old Kingdom and has been known and usually ignored since the end of the 19th century. For references to the dates of the Balat coffin and D1D, see Jürgens, Grundlinien, 70 n. 21.

5 As in N. Picardo, "Semantic Homicide" and the So-called Reserve Heads: The Theme of Decapitation in Egyptian Funerary Religion 
greeted my discussion and the confidence with which it is still invoked are signs of what I believe to be the actual state of affairs. Though the theory has been critiqued several times, there is still a large proportion of Egyptologists who maintain it. The result in the near term will probably be cognitive dissonance in the field, as the time-honoured commonplace staggers on despite the evidence and arguments.

But the facts have a way of prevailing in the end. The present discussion will contribute to the inquiry on the topic by identifying the roots of the theory's original formulation, and in this way it hopes to complement the general description by Harco Willems of the socio-political environment at its academic birth. ${ }^{6}$ In locating its origin, my discussion will highlight its chief flaw-that it rests upon negative evidence-and argue that the history of religion in the Old Kingdom should rather be based on the evidence that does exist. This point will serve as a springboard for a consideration of two means of access to the afterlife in the Old Kingdom as expressed in non-royal and royal tombs, knowledge and ritual. Drawing attention to representations of ritual found in royal and non-royal tombs, I hope to show a commonality of belief and practice between king and elite.

\section{The birth of the democratisation theory}

It is not difficult to find an exposition of the theory. The description of Rosalie David should be perfectly familiar, for instance: 'Whereas during the Old Kingdom, only the king could expect to enjoy an individual immortality, in Dynasties 11 and 12, this was replaced with a democratisation of beliefs'. 7 Such accounts usually do not feel obliged to cite a reference in substantiation, so seemingly well understood is the theory. But the story of its origins helps clarify its actual supports and claims.

Mark Smith observes that the democratisation theory had its advent as early as James Henry Breasted's Development of Religion and Thought in Ancient Egypt. ${ }^{8}$ Published in 1912, four years after Kurt Sethe's synoptic presentation of the Pyramid Texts began to appear, ${ }^{9}$ his was the first study to make use of these texts in a comprehensive way. It was also the first to situate them within the context of already known corpora, namely the Book of the Dead from the New Kingdom and one from the Middle Kingdom that soon came to be called 'Coffin Texts'. Breasted observed that

and Some Implications for the Old Kingdom', JARCE 43 (2007), 226 with references to other adherents in his n. 32 and J.P. Allen, 'Some Aspects of the Non-royal Afterlife in the Old Kingdom', in M. Bárta (ed.), The Old Kingdom Art and Archaeology (Prague 2006), 9.

6 See Willems, Les Textes des Sarcophages, 135-142, and Willems, in Assmann and Roeder (eds), Handbuch der altägyptischen Religion.

7 R. David, Religion and Magic in Ancient Egypt (London 2002), 154.

8 Smith, in Dieleman and Wendrich (eds), UCLA Encyclopedia of Egyptology, 2.

$9 \quad$ K. Sethe, Die altaegyptischen Pyramidentexte I (Leipzig 1908). in the Old Kingdom the Pyramid Texts 'were all intended for the king's exclusive use, and as a whole contain beliefs which apply only to the king'. The key reason for this assessment was the 'significant fact that the nobles of the age made practically no use of the Pyramid Texts in their own tombs'. ${ }^{10}$ But in the Middle Kingdom ${ }^{11}$ such texts were 'largely appropriated by the middle and official class' in a situation Breasted described as 'the popularization of the mortuary customs of the upper classes'. ${ }^{12}$ To label the mortuary literature appearing in the Middle Kingdom, Breasted coined the term Coffin Texts, ${ }^{13}$ chosen for the typical medium on which mortuary texts then appeared. In terms of content, they were deemed by him to be similar to the Pyramid Texts, 'identical in function but evidently more suited to the needs of common mortals. ${ }^{14}$ As a corollary to this development, the non-royal dead in the Middle Kingdom received the prefix 'Osiris' to his name, 'so that he not only as of old entered the kingdom of Osiris [sc. the necropolis] to enjoy the god's protection and favor, but he now became Osiris and was conceived as king. ${ }^{15}$

As far as the supports of the theory are concerned, Breasted advanced only this: the attested disparity of social distribution of mortuary literature between the Old and Middle Kingdoms, a similar disparity in the use of the epithet 'Osiris' as a mark of spiritual attainment, and an assumed difference in appropriateness of content between Pyramid Texts and Coffin Texts. This simple combination constitutes the core of the theory.

It may have struck the reader that in none of the given quotations does Breasted use the term democratization itself, preferring instead 'popularization of the mortuary customs of the upper classes' and 'popularization of the old royal hereafter'. ${ }^{16}$ To be sure, he does employ the verb democratize twice, ${ }^{17}$ but it was up to his colleague and

\footnotetext{
10 Both quotations are from J. H. Breasted, Development of Religion and Thought in Ancient Egypt: Lectures Delivered on the Morse Foundation at Union Theological Seminary (New York 1912), 99. cf similarly id., The Oriental Institute of the University of Chicago. A Beginning and a Program (Chicago 1922), 74; id., The Oriental Institute (Chicago 1933), 152; id., The Dawn of Conscience (New York 1933), 223-249.

11 Called by Breasted the 'Feudal Age', which he defines as 'a thousand years after the Old Kingdom', and specifically as the 'Twelfth Dynasty', and thus the 'early Feudal Age' with him is coeval to 'early in the Twelfth Dynasty', namely the reign of Amenemhat I (id., Development, 167, 180, and 249 with n. 1).

12 ibid, 272, with this and the discussion of which it is part paraphrased in id., The Dawn of Conscience, 235.

13 id., Development, 273 n. 1.

14 ibid, 272.

15 ibid, 256; see also ibid, 257, with these two pages paraphrased in id., The Dawn of Conscience, 223.

16 id., Development, 257.

17 loc. cit.
} 
friend Alan H. Gardiner to actually use the noun itself. He did so in 1915, just three years after the appearance of Breasted's Development of Religion and Thought. The point is not trivial, because Gardiner actually makes no reference to Development. And through his discussion one is led to an even older point of origin. In discussing the New Kingdom tomb of Amenemhat, Gardiner remarked:

The investigations of the last few years have made it increasingly evident that until far down in the Old Kingdom no dead man except the Pharaoh himself was identified with Osiris.... Naturally enough the contemporary nobles would be eager to imitate on their own behalf the splendid obsequies of their sovereigns, and the custom of doing so, hesitatingly adopted at first, seems to have become universal before the Middle Kingdom. No adaptation of the ritual to the non-royal character of its new employers seems to have been made, so that we find among the funeral furniture on the sarcophagi and on the tomb-walls belonging to private individuals such unsuitable objects as the statues with kingly crowns.... The identification of all virtuous dead men with Osiris was the ultimate consequence of this usurpation of the royal funerary ritual. ${ }^{18}$

Although Gardiner's presentation is quite similar to Breasted's, he does not cite him. And although he couches his discussion in terms of ritual and display, he supports his exposition as follows: 'On the "democratization" of the old funerary literature and the like, see especially Sethe, Pyramidentexte, Vorwort, vii'. ${ }^{19}$ The evidential substantiation for these assertions, then, is to be found in the demographic distribution of mortuary texts, concerning which one is to consult (especially) Sethe.

Sethe's Pyramidentexte is of course the same work that had inspired Breasted, and it is in Sethe's volume that the ultimate origin of the theory may be found. At the place indicated, he asserts that together the texts of the five royal pyramids transcribed in his autographed volumes constitute 'eine enggeschlossene Gruppe'.

And yet in the next breath he observes that texts from later monuments of a different kind were then being continually discovered, and that they contained precisely the same material as that of the 'tightly closed group'. How can that be? In the modern construction of a corpus out of ancient material, any reasonable criterion can serve to make a division, and in this manner one's already colossal workload can be reduced. Consider this: the text of an edition of Moby Dick from the 19th century of course has nothing to do with one published in the 20th century-right? The point is that the division is artificial. The material is real, and time is natural, but the division is not. Insofar as they each have an integral identity beyond their physical manifestations, the texts of the 'closed group', those of the five

\footnotetext{
18 A. H. Gardiner, in Nina de Garis Davies and A. H. Gardiner, The Tomb of Amenemhèt (No. 82) (TTS 1; London 1915), 55.

19 loc. cit., n. 1.
}

kingly pyramids, escape any boundary put around them. They pour out into the tombs of contemporaneous queens and flow on while maintaining their identities into the Middle Kingdom, no matter the artificial line one draws around them-and this much is already admitted in the first place by Sethe, the one doing the drawing.

But the division is not merely temporal. According to Sethe these later texts of the same sort as the 'closed group' belonged

vielmehr einer weiteren Entwicklungsstufe jener alten Totenliteratur an. In den Pyramiden von Sakkara treten uns die Pyramidentexte noch ihrer ursprünglichen Bestimmung gemäß als Königstotentexte verwendet (denn das sind sie ihrem Inhalte nach ursprünglich ausschließlich gewesen) entgegen; auf den anderen [sc. later] Denkmälern sind sie (oder richtiger eine Auswahl bestimmter, immer wiederkehrender Texte daraus) als allgemeine Totentexte für jedermann gebraucht. Es ist hier also wieder einmal das geschehen, was wir so oft beobachten können: was einst nur dem König zustand, haben sich allmählich die Untertanen angemaßt. Wie sie in dem "Gerätefries" ihrer Särge eine königliche Grabausrüstung für sich beanspruchten, haben sie sich auch die alten Königstotentexte angemaßt und nennen sich, was eigentlich nur beim König Sinn hatte, „Osiris“. Diese Anmaßung der Königsvorrechte ist eine charakteristische Erscheinung für die Zeit nach dem Zusammenbruch des alten Reichs, das Mittelalter der ägyptischen Geschichte (Dyn. 7 ff). In diese Zeit wird man denn wohl auch die ältesten Beispiele der Anwendung der Pyramidentexte auf nichtkönigliche Personen zu setzen haben. Zum Teil mögen sie den Pyramiden der sechsten Dynastie zeitlich noch ziemlich nahe stehen; zum Teil stammen sie auch sicher erst aus dem eigentlichen mittleren Reich (Dyn. 12). ${ }^{20}$

The central points of Breasted and Gardiner are summed up in this simple and seminal paragraph: the Pyramid Texts were originally for the exclusive use of the king. When they are later found as general mortuary texts for everyone (jedermann), it is through an appropriation (anmaßen, Anmaßung) of royal prerogatives (Königsvorrechte). This appropriation included laying claim to the title 'Osiris', which properly only had meaning in reference to the king - 'was eigentlich nur beim König Sinn hatte'. In short, the comparatively narrow distribution of mortuary texts in the Old Kingdom and its expansion in the Middle Kingdom are linked with a demographic expansion of privileged access to a deified afterlife.

\section{The birth of the term Coffin Texts}

This is an important detail, because Breasted, Gardiner and Sethe were the same three scholars who were instrumental in the modern reception of the Old and Middle Kingdom mortuary literature. The term Coffin Texts was coined by Breasted in the pages of Development of Religion and

20 Sethe, Die altaegyptischen Pyramidentexte I, vii-viii. 
Thought, and it was together with Gardiner that he launched the Coffin Texts Project of the University of Chicago's Oriental Institute. After the project's initiation in 1922, ${ }^{21}$ and after their erstwhile partner Pierre Lacau withdrew, ${ }^{22}$ Breasted asked Sethe to nominate one of his students to assume the greater burden of the publication of the Middle Kingdom material, and that was Adriaan de Buck. ${ }^{23}$

As the chief datum of the theory resides in the appearance of non-royal mortuary texts in the Middle Kingdom and the absence of such texts in the Old Kingdom, and as these three were instrumental in crafting their modern reception, I believe it is justifiable to say that the democratisation theory is bound up with the modern conceptual division between the two corpora. If this division rested merely in a temporal division between two strata of a single body of literature and a concomitant distinction in social distribution, there would surely be no trouble. But, as shown above, the distinction also has to do with an evaluation of the purpose and nature of content: the Pyramid Texts are defined as exclusively for the use of the king and contain beliefs exclusively applicable to him, and when they are later found in the tombs of non-royal persons, the development is characterised as an 'usurpation' and as 'unsuitable'-notions which resonate to this day. As one recent popular book has it, the Pyramid Texts as a body of literature were 'intended solely for the king', and these were 'adapted for the use of non-royal persons' and as such are called 'Coffin Texts'. ${ }^{24}$ With another popular account, 'the old religious texts for the protection of the king were usurped and adapted for more widespread use', and the 'revised texts' are now known as 'Coffin Texts'. ${ }^{25}$ Exclusively for the king, unsuitable, usurpation, adaptation, revision, appropriation: the practical definitions of the terms are wedded to the democratisation theory. It is not only a distinction by time. They are defined by us today by perceived social intention and use of the literature which they exemplify.

Breasted once asserted that Pyramid Texts are to be 'sharply distinguished' from Coffin Texts, ${ }^{26}$ but how can they be, when they share a considerable body of material-over 400 texts-verbatim? The terms obscure an underlying continuum between mortuary literature from

\footnotetext{
21 Breasted, The Oriental Institute of the University of Chicago. A Beginning and a Program, 78.

22 Breasted, A Beginning and a Program, 161.

23 Breasted, A Beginning and a Program, 162. To be clear, A. de Buck was hired in 1925 specifically to replace L. Bull as the assistant of A.H. Gardiner.

24 T. G. H. James, A Short History of Ancient Egypt (Baltimore 1998), 59 and 69.

25 A.J. Spencer, Death in Ancient Egypt (New York 1982), 141.

26 Breasted, A Beginning and a Program, 152.
}

the two periods. ${ }^{27}$ They create a digital (mis)representation of an analogue and largely lost reality. It is no accident that some of the same scholars who have challenged the democratisation theory have done so while also challenging a conceptual division between Pyramid and Coffin Texts, as with Peter Jürgens and Bernard Mathieu. ${ }^{28}$ Contributing to that discussion is the identification of three kinds of general continuities between Old and Middle Kingdom mortuary literature: the verbatim transmission of texts, the Middle Kingdom production of variants of Old Kingdom texts, and the Middle Kingdom construction of new texts out of the Old Kingdom material. ${ }^{29}$ Even when a text appears to belong to a strictly Middle Kingdom genre, points of contact with the Old Kingdom material can be found. ${ }^{30}$

Where, precisely, is the adaptation of fundamentally inappropriate content?

\section{Pyramid Texts as manifestation of a wider body of literature}

From the point of view of the Middle Kingdom, the nonroyal display of royal iconography in text and image was clearly acceptable. But display in text and image is not the same as use in ritual action and religious belief. If in the Old Kingdom the same mortuary literature was used by nonroyal persons, then the physical absence of mortuary texts in their tombs must instead be a sign of the constraints of decorum ${ }^{31}$ not lack of access to the afterlife and the texts and rituals by which it was attained.

\footnotetext{
27 cf H.M. Hays and W. Schenck, 'Intersection of Ritual Space and Ritual Representation. Pyramid Texts in Eighteenth Dynasty Theban Tombs', in P. F. Dorman and B.M. Bryan (eds), Sacred Space and Sacred Function in Ancient Thebes (SAOC 61; Chicago 2007), 105 with $\mathrm{n} .91$. The terms also conceal the fact that texts of several genres come under their overlapping umbrellas, as observed by L. Gestermann, Die Überlieferung ausgewählter Texte altägyptischer Totenliteratur ('Sargtexte') in spätzeitlichen Grabanlagen. I (ÄgAbh 68; Wiesbaden 2005), 7 and 16 with nn 21, 55, and 56, and Willems, in Assmann and Roeder (eds), Handbuch der altägyptischen Religion. 28 See already W. Barta, Die Bedeutung der Pyramidentexte für den verstorbenen König (MÄS 39; Munich 1981), 62; J. P. Allen, 'Funerary Texts and Their Meaning', in S. D'Auria, P. Lacovara and C. H. Roehrig (eds), Mummies and Magic. The Funerary Arts of Ancient Egypt (Boston 1988), 40. See Jürgens, Grundlinien, 85, where 'keine Zäsur' is seen between Pyramid Texts and Coffin Texts, but 'Damit soll nicht gesagt sein, dass Pyramidentexte und Sargtexte schlicht „dasselbe“ sein'. See also Mathieu, in Bickel and Mathieu (eds), D'un monde à l'autre, 247-262

29 See H. M. Hays, The Typological Structure of the Pyramid Texts and Its Continuities with Middle Kingdom Mortuary Literature (University of Chicago Ph.D. dissertation 2006), 105-107, 188-191, 227-228, and 290-293.

30 H. M. Hays, 'The Mutability of Tradition: The Old Kingdom Heritage and Middle Kingdom Significance of Coffin Texts Spell 343', JEOL 40 (2007) 43-59.

31 cf J. Baines, 'Modelling Sources, Processes, and Locations of
} 
Absence of mortuary texts in Old Kingdom non-royal tombs was the core fact in the construction of the democratisation theory. According to it, only royal persons have such texts in the Old Kingdom, and therefore they were the only ones who used them and had access to an afterlife. It was precisely this point that Mathieu challenged in his first critique of the theory. As he remarked, it has yet to be demonstrated that there ever truly was a royal exclusivity in mortuary literature, and the absence of texts in non-royal sepulchres would constitute but a fragile argument that there was. ${ }^{32}$ Later he asserts, 'Que les particuliers de l'Ancien Empire ne possèdent pas de textes funéraires dans leurs sépultures ne signifie pas qu'ils n'en bénéficiaient pas. Après tout, nul n'imagine que les souverains du Moyen Empire, par exemple, ne bénéficiaient pas d'une destinée glorieuse dans l'au-delà, sous prétexte qu'il n'y a pas de textes gravés dans leurs pyramides'. ${ }^{33}$

Indeed, the absence of religious texts from royal Middle Kingdom tombs is a point left unaddressed by the theory. By its logic one should have to understand that only non-royal persons had access to the afterlife at that time-an absurdity refutable by consultation of royal texts from outside the tomb, though the proof (should one care to pursue it) will not come from exemplars of the mortuary literature. No, the absence of religious texts in royal tombs of the Middle Kingdom underscores the difference between textual display and religious action and belief. While the contents of displayed texts do offer a window into ritual and belief, the actual performances and thoughts they represent are lost in time. Texts are not equivalent to belief and action; they overlap them. Display of texts is not the same as religious thought and practice.

Nicole Alexanian has argued that changes in customs of burial assemblages between social classes reflect processes of social distinction. ${ }^{34}$ From this point of view, the display of texts is in part subsumed under the heading fashion. Changes in fashion play a game of equilibrium and negotiation, where the intrinsic meaning of what is shown matters less than the differentials and similarities of presentation. ${ }^{35}$ Religious texts were not inscribed in tombs so as to display the keys to heaven as a proof that a certain social group had access to them while others did not. Their inscription was motivated by the exercise of taste according to an unwritten code of practice, an habitus of self-constructed

Early Mortuary Texts', in Bickel and Mathieu (eds), D'un monde à l'autre, 39; and Willems, in Assmann and Roeder (eds), Handbuch der altägyptischen Religion.

32 Mathieu, Égypte Afrique et Orient 12 (1999) 20.

33 Mathieu, in Bickel and Mathieu (eds), D'un monde à l'autre, 257.

34 N. Alexanian, 'Tomb and Social Status. The Textual Evidence', in M. Bárta (ed.), The Old Kingdom Art and Archaeology (Prague 2006), 8 with n. 24.

35 cf R. Barthes, Essais critiques (Paris 1964), 156. distinction. ${ }^{36}$ Because the Middle Kingdom elite had resurrected a centuries-old tradition to decorate their tombs, it was natural that the contemporaneous kings did not follow suit. By not doing so, they reinforced existing social distinctions. But these choices of display are not coextensive with religious action and belief.

It cannot be the case that the surviving bodies of texts - call them 'Pyramid Texts' and 'Coffin Texts' if you will ${ }^{37}$ - circumscribe the entirety of Old and Middle Kingdom mortuary literature that had once existed in text, action, and belief. As a discursive formation, the Old Kingdom mortuary literature extended beyond what has survived in pyramids of kings and queens. Indeed, this body of literature must have existed well prior to its first attestations in monumental stone. Its component members, its texts, had been composed and recited long before King Unas was born. To adorn the walls of his crypt, he transposed texts from other settings in life.

The most immediate testimony of this fact may be found in shattered fragments of inscriptional decoration from the pyramid temple of Sahure, remnants of a kind of offering list which is keyed in with offering ritual recitations in the Pyramid Texts. Ninety offering ritual Pyramid Texts correspond point for point to the items of the canonical Type A offering list preserved in part in Sahure's fragments. Such offering lists identify a series of rites by specifying the items to be manipulated therein-usually foodstuffs to be presented-while the Pyramid Texts counterparts provide the recitations as well as the same specifications in the same order. ${ }^{38}$ The fragments serve to connect Pyramid Texts to

36 cf P. Bourdieu, Distinction. A Social Critique of the Judgement of Taste (trans R. Nice; Cambridge 1998), 466. cf also the concept of 'social marks' in M. Baud, Famille royale et pouvoir sous l'Ancien Empire égyptien (BdE 126; Cairo 1999), 193-194.

37 To be precise, these modern terms should make reference strictly to texts edited as such. Thus I define Pyramid Texts as 'mortuary texts attested in the Old Kingdom and published as such', and Coffin Texts as 'mortuary texts attested in the Middle Kingdom and published in the eight volumes of the Oriental Institute's Coffin Texts series'.

38 Willems, in Assmann and Roeder (eds), Handbuch der altägyptischen Religion; Smith, in Dieleman and Wendrich (eds), UCLA Encyclopedia of Egyptology, 9; Hays, Typological Structure, 94-102; Baines, in Bickel and Mathieu (eds), D'un monde à l'autre, 21 with n. 29; Allen, in D'Auria, Lacovara and Roehrig (eds), Mummies and Magic, 39; H. Willems, Chests of Life. A Study of the Typology and Conceptual Development of Middle Kingdom Standard Class Coffins (MVEOL 25; Leiden 1988), 203; W. Barta, Die altägyptische Opferliste von der Frühzeit bis zur griechisch-römischen Epoche (MÄS 3; Berlin 1963), 67; A. M. Blackman and M. R. Apted, The Rock Tombs of Meir V (ASE 28; London 1953), 43; S. Hassan, Excavations at Gîza VII, part 2 (Cairo 1948), 46, 77, and 157; H. Junker, Gîza II (Vienna 1934), 76 and 80-82 (and note that the distinction he attempts to make between a royal and non-royal list through reference to regalia presentations can be understood quite otherwise). See also the libation stand bearing PT 32 discussed in J. Leclant, 'Un support d'autel à 
an above-ground place of performance: the subterranean texts in question are copies of mortuary texts that had been recited as scripts in the above-ground pyramid temple. This means that they had been transposed from a pre-existing setting from outside the burial chambers. In their aboveground context, they served as ritual scripts. In the crypt, they served as decoration, an efficacious artificial voice. ${ }^{39}$ This solid connection shows that (at least) these texts had already existed long before being physically attested as Pyramid Texts, and it therefore shows that the actual extent of the Old Kingdom mortuary literature goes beyond the physical exemplars we now have.

The testimony for this body of literature from outside the crypt appears only in remnants. The recent, unprecedented discovery of an inscribed fragment of a wooden chest of a queen of Pepy $\mathrm{I}^{40}$ is a reminder of just how fragile wood and papyrus are. And of course it is precisely in the form of the latter that the ritual scroll would have existed. ${ }^{41}$ The Pyramid Texts constitute only a portion of the total discursive formation. The existence and use of all the other lost stone, wood, and papyrus exemplars (not to mention acts of speech) only seem less real because they are not tangible today. And just as one might evidentially infer that the Middle Kingdom king had access to an afterlife and had use of mortuary literature, so is it inferable that non-royal persons of the Old Kingdom had access and use of the same kinds of texts as are preserved in the pyramids. As we shall see.

The permeable social boundaries of the total discursive body may be located by consideration of all the evidence, including statements in the Pyramid Texts themselves. ${ }^{42}$

libations du temple haut de Pépi Ier', in S. Israelit-Groll (ed.), Studies in Egyptology Presented to Miriam Lichtheim II (Jerusalem 1990), 653-655, for which reference I am deeply grateful to A. J. Morales. 39 On the concept of artificial voice, see J. Assmann, Images et rites de la mort dans l'Égypte ancienne l'apport des liturgies funéraires (Paris 2000), 32; and J. Assmann, Tod und Jenseits im Alten Ägypten (Munich 2001), 335.

40 See J. Leclant and A. Labrousse, 'Découvertes récentes de la Mission archéologique française à Saqqâra (campagnes 2001-2005)', CRAIBL (2006) 108 Fig. 4.

${ }^{41}$ See PT 217 on face $A$ of MafS Papyrus T 2147, with a possible date in the area of the sixth through eleventh dynasties: C. Bergerel Naggar, 'Textes des Pyramides sur papyrus dans les archives du temple funéraire de Pépy Ir', in S. Bickel, B. Mathieu (eds), D’un monde à l'autre, 85-89 with n. 13 and Fig. 1. On mistakes in the Pyramid Texts showing that they had been transcribed from hieratic, and therefore from papyrus or leather master copies, see Sethe, Die altaegyptischen Pyramidentexte IV (Leipzig 1922), 125-127.

42 A refutation of the idea that some Pyramid Texts contain explicit statements concerning the exclusion of lower classes from the afterlife may be found in O.I. Pavlova, 'Rechit in the Pyramid Texts: Theological Idea or Political Reality', in J. Assmann and E. Blumenthal (eds), Literatur und Politik im pharaonischen und ptolemäischen Ägypten. Vorträge der Tagung zum Gedenken an Georges Posener
The presence of such words as $m r$ 'pyramid' ${ }^{43}$ would seem to indicate that some texts had been composed specifically for a royal beneficiary, since that architecture was distinctive to the highest stratum of society. But equally it may be inferred by content that some Pyramid Texts had not been composed for a royal beneficiary, as has been pointed out by Edward F. Wente. ${ }^{44}$ For example PT 467 has the dead king declaring that he has not striven with... the king. In that text, as written, the ni-sw.t must be a person separate from the deceased. This also is the case with PT 486, in which the dead king declares that he is not taken away to the king and affirms that he is unpunished. Unpunished? But the fundamental principle of sovereignty is (paradoxically) to embody the law and to be exempt from it. ${ }^{45}$ As composed and transcribed onto the walls of the tombs of Pepy I and Pepy II, these texts do not situate the deceased in the royal social class, or else they would be meaningless. The content of these texts and others ${ }^{46}$ indicates that multiple social strata contributed to the production and participated in the use of the Pyramid Texts. Further, material seemingly composed with a particular social class in mind could be taken up by others. In the case of texts like PT 467 and 486, one sees the king adopting material written for those of lesser social status and doing so without adaptation-and yet the theory claims that the Pyramid Texts were for exclusively royal use. Because the larger corpus of Old Kingdom mortuary literature had also existed on wood and papyrus, in point of fact one cannot know the full extent of its distribution and use without consultation of evidence beyond mere physical possession.

\section{The nature of the desired afterlife: Osiris and Akh}

One of the elements of the democratisation theory is that, in the Old Kingdom, only the king aspired to become Osiris, as indicated by the use of that god's name prefixed to the king's. It is certainly the case that spiritual attainment was expressed by identifying oneself with Osiris. In the Pyramid Texts the formulation wir $N N$ is abundantly attested in texts performed by priests for the deceased, ${ }^{47} \mathrm{a}$

5. - 10. September 1996 in Leipzig (BdE 127; Cairo 1999), 95, 101 , and 104 .

43 PT $534 \$ 1277 b ;$ PT $599 \$ 1649$ c; PT $600 \$ 1653 b-c ;$ PT 601 \$1661c.

44 E. F. Wente, 'Mysticism in Pharaonic Egypt?', JNES 41 (1982), 176 n. 118. See also Smith, in Dieleman and Wendrich (eds), UCLA Encyclopedia of Egyptology, 7; C. Eyre, The Cannibal Hymn. A Cultural and Literary Study (Liverpool 2002), 66; and L. Kákosy, 'The Pyramid Texts and Society in the Old Kingdom', Annales Universitatis Scientarum Budapestinenisis de Rolando Eotvos Nominatae. Section Historica 4 (1962), 4-5 and 9-10.

45 See G. Agamben, Homo Sacer. Sovereign Power and Bare Life (Stanford 1998), 15-29.

46 See also PT $571 \$ 1468 \mathrm{c}-1469 \mathrm{a}$ and PT $726 \$ 2253 \mathrm{~b}-\mathrm{d}$.

47 Aside from the $w$ sir NN formula, see the explicit identifications of the deceased as this god at PT $258 \$ 308$ a; PT $259 \$ 312 \mathrm{a}$; PT 
category which may therefore be called sacerdotal. ${ }^{48}$ But the social distinction supposed by the theory is again based on negative evidence-and doubly so, since the combination of epithet plus name is attested almost exclusively in the Pyramid Texts themselves. But it is noteworthy that, outside the royal sepulchres, the formula Osiris <name $>$ is attested in the Old Kingdom only in application to nonroyal persons,$^{49}$ a detail that was apparently unknown to the three authors of the theory at the time of its crafting. Based on a careful typological dating of non-royal burial chambers, Edward Brovarski has shown that non-royal persons employed the epithet Osiris as early as the middle part of the reign of Pepy II..$^{50}$

This is about a century later than the formulation's attestation in the pyramid of Unas, but there are factors that warrant caution in seizing upon the temporal difference in the construction of a historical picture. Since the use as epithet also continued to be rare in non-royal venues during the First Intermediate Period, one may suppose with Khaled Daoud that its display at that time might still have been thought provocative. ${ }^{51}$ In my view, this is an assessment which concerns what was fitting to represent. In other words, it is again a question of fashion. Another important factor is that the non-royal use of the epithet is ordinarily found before the Middle Kingdom in the context of the offering list, which is a representation of the offering ritual, ${ }^{52}$ and the Type A offering list is found in non-royal tombs long before the first appearance of the

437 \$793b; PT $468 \$ 895 \mathrm{c}-\mathrm{d} ;$ PT $493 \$ 1059 \mathrm{~d}-\mathrm{e} ;$ PT $535 \$ 1282 \mathrm{~b}$; PT $600 \$ 1657 \mathrm{a}$; PT $624 \$ 1761 \mathrm{~d}$; PT $650 \$ 1833 \mathrm{a}$ and \$1833c; PT $684 \$ 2054$; PT $687 \$ 2076 \mathrm{c}$; and PT $690 \$ 2097 \mathrm{a}$ and $\$ 2103 \mathrm{c}-\mathrm{d}$. As these passages are not susceptible to a reinterpretation of ambiguous grammatical syntax, they show that the relationship between the deceased and the god really was one of identity ('is' rather than 'of', pace M. Smith, 'Osiris NN or Osiris of NN?', in B. Backes, I. Munro and S. Stöhr (eds), Totenbuch-Forschungen: Gesammelte Beiträge des 2. Internationalen Totenbuch-Symposiums, Bonn, 25. bis 29. September 2005 (Wiesbaden 2006), 325-337). In respect to being Osiris, see also CT 42 I 178d; CT 227 III passim; CT 237 III 309b-c; CT 269 IV 7k; CT 507 VI 92b; CT 577 VI 193c; CT 599 VI 215g-h; CT 666 VI 293d; CT 828 VII 28v, q. CT 227 is most notable in this regard, since the title given to it in one of its exemplars is hpr.w $m$ wsir 'Becoming Osiris'. The deceased aspired to become Osiris in the Old and Middle Kingdoms.

48 On this term, see H. M. Hays, 'Old Kingdom Sacerdotal Texts', JEOL 41 (2009) 49.

49 Nordh, Aspects, 169.

50 E. Brovarski, 'The Late Old Kingdom at South Saqqara', in L. Pantalacci and C. Berger-el-Naggar (eds), Des Néferkarê aux Montouhotep. Travaux archéologiques en cours sur la fin de la VIe dynastie et la Première Période Intermédiare (Lyon 2005), 63.

51 K. A. Daoud, Corpus of Inscriptions of the Herakleopolitan Period from the Memphite Necropolis. Translation, Commentary and Analyses (BAR S1459; Oxford 2005), 117.

52 See above n. 38.
Pyramid Texts-indeed, even earlier than the fragments of this list from the pyramid temple of Sahure. The actual recitations of the ritual, naturally not shown in the offering lists, habitually employ the wsir <name> formulation. This fact creates a quandary: before the reign of Pepy II, how was the non-royal deceased referred to in the offering ritual? There is no evidence to provide an answer.

Instead of creating history out of silences, it would be better to draw conclusions from what can be positively seen. The word wsir emerges some fifty years before it is found in the Pyramid Texts of Unas, and it does so, remarkably, in a non-royal tomb. As Mathieu observes, ${ }^{53}$ the first securely datable attestation is from the middle of the fifth dynasty during the reign of Niuserre, in the tomb of the non-royal personage Ptahshepses. There, it appears in the divine formula $h t p-d i$-wsir 'the offering which Osiris gives' ${ }^{54}$ But the god's entry to the divine formula $-\underline{h t p-d i-<\operatorname{god}>- \text { is }}$ part of a wider phenomenon in the fifth dynasty. Whereas in the fourth dynasty only Anubis is featured in the divine formula, ${ }^{55}$ in the fifth multiple gods appear, ${ }^{56}$ including

\footnotetext{
53 B. Mathieu, 'Mais qui est donc Osiris? Ou la politique sous le linceul de la religion (Enquêtes dans les Textes des Pyramides, 3)', ENIM 3 (2010) 77 with nn 3-4, where it is noted that a further instance of the name may be dated even earlier. On the question of the date of Osiris, add to Mathieu's references: A. Bolshakov, 'Princess hm.t-rr(w): The First Mention of Osiris?', CdE 67 (1992) 203-210; id, 'Osiris in the Fourth Dynasty Again? The False Door of Intj, MFA 31.781', in H. Györy (ed.), Mélanges offerts à Edith Varga: 'Le lotus qui sort de terre' (Budapest 2001), 65-80.

${ }_{54}$ BM EA 682, for which see T. G. H. James, Hieroglyphic Texts from Egyptian Stelae etc. Part I Second Edition (London 1961), 17 and pl. 17, P. F. Dorman, 'The Biographical Inscription of Ptahshepses from Saqqara: A Newly Identified Fragment', JEA 88 (2002), 95-110, and N. C. Strudwick, Texts from the Pyramid Age (Writings of the Ancient World 16; Atlanta and Leiden 2005), 303-305.

55 W. Barta, Aufbau und Bedeutung der altägyptischen Opferformel (ÄF 24; Gluckstadt 1968), 8 and 225 (under 'Jnpw'), and T. DuQuesne, The Jackal Divinities of Egypt I. From the Archaic Period to Dynasty X (London 2005), 144 and 384-385. One of the earliest attestations is from the tomb of Metjen, Berl. Inschr. $1105 \mathrm{~L}$ (Aegyptische Inschriften aus den Königlichen Museen zu Berlin (Leipzig 1913), 86, or any of the more recent publications listed in Strudwick, Texts from the Pyramid Age, 451 (\#108)). Other secure fourth dynasty attestations include D. Dunham and W. K. Simpson, The Mastaba of Queen Mersyankh III. G 7530-7540 (Giza Mastabas 1; Boston 1974), e.g. Figs 3b and 7; W. K. Simpson, The Mastabas of Kawab, Khafkhufu I and II (Giza Mastabas 3; Boston 1978) Figs 24-25; H. Junker, Gîza I (Vienna 1929), fig. 57, 1.

56 cf J. G. Griffiths, The Origins of Osiris and His Cult (Leiden 1980), 113, and Barta, Aufbau und Bedeutung der altägyptischen Opferformel, 15. Other gods introduced to the divine formula in the fifth dynasty include the Western Desert (LD II $44 \mathrm{~b}$ and LD II 81), Maat (cited in B. Begelsbacher-Fischer, Untersuchungen zur Götterwelt des Alten Reiches im Spiegel der Privatgräber der IV. und V. Dynastie (Freiburg 1981), 102); Geb (A. Mariette, Les mastabas de l'ancien empire (Paris 1889), 186); as well as Wadyt, Ptah, Montu, Neith, Re and Hathor,
} 
Osiris $^{57}$ and Khentimentiu 'Foremost of the Westerners'. ${ }^{58}$ Thus the advent of Osiris coincides with the modification of a traditional religious formula.

Aspects of the treatment of Osiris, Anubis and Khentimentiu suggest that their roles were being refined in the fifth and sixth dynasties. Two attestations of the term bnti-imn-tiw from the Archaic Period-at which time it shows its oldest writing, with $m n$-game-board sign and jackal determinative - were previously understood to represent an independent jackal deity, ${ }^{59}$ but Terence DuQuesne has recently asserted that the jackal sign in question should be read as inpw. ${ }^{60}$ This fits in with the historical attestations of bnti-imn.tiw and inpw in connection with the offering formula in the fourth and fifth dynasties. First only inpw is found in it in the fourth dynasty, then bnti-imn-tiw as an epithet of inpw in the early fifth dynasty, ${ }^{61}$ and then bntiimn.tiw independently in the mid- to late fifth dynasty. ${ }^{62}$ Thus Khentimentiu seems first to be an epithet or manifestation of the god Anubis before splitting off from him.

The split seems to occur at about the time that the name of Osiris is first attested, and yet at about that same time, the newly attested god is already intimately associated with Khentimentiu. The term bnti-imn.tiw begins to be appended to the name Osiris as an epithet in the late fifth dynasty or early sixth dynasty, ${ }^{63}$ and in the Middle

for references to which see DuQuesne, Jackal Divinities of Egypt I, 145 with n. 19.

57 For example Mariette, Mastabas, 149 and 259; H.T. Mohr, The Mastaba of Hetep-Her-Akhti (MVEOL 5; Leiden 1943), 33; M.A. Murray, Saqqara Mastabas. Part I (ERA 10; London 1905), pls 7 and 20; H. Junker, Gîza VII, (Vienna 1944), fig. 85; LD II 44b, LD II 65, LD II 75, LD II 89; BM 1275, for which see James, Hieroglyphic Texts Part I, 20 and pl. 21; CG 1332, CG 1424, and CG 1506, for which see L. Borchardt, Denkmäler des Alten Reiches (ausser den Statuen) im Museum von Kairo Nr. 1295-1808. Teil I (Berlin 1937), 16, 106, 211 respectively, and CG 1563, for which see L. Borchardt, Denkmäler des Alten Reiches (ausser den Statuen) im Museum von Kairo Nr. 1295-1808. Teil II (Cairo 1964), 26.

58 For example Mariette, Mastabas, 149 and 259; BM 682; LD II 81. 59 W. M. F. Petrie, Abydos Part II (EEF 24; London 1903), pl. 12 (\#278); G. Dreyer, 'Ein Siegel der frühzeitlichen Königsnekropole von Abydos', MDAIK 43 (1987), 36 fig. 3 and pls 4 and 5; see further DuQuesne, Jackal Divinities of Egypt I, $28 \$ 31$.

${ }^{60}$ See DuQuesne, Jackal Divinities of Egypt I, 384-385 \$492. However, to my knowledge the epithet $n b 3 b d w$ is never applied immediately to Anubis; that role is particular to Khentimentiu and Osiris; see below, n. 67.

${ }_{61}$ For example LD II 48, lower band, and LD II 101a; see further citations in DuQuesne, Jackal Divinities of Egypt I, 162-163 \$177.

62 See the citations above, n. 58; see further citations in DuQuesne, Jackal Divinities of Egypt I, $163 \$ 178$.

63 In the tomb of Ptahhotep at Saqqara (LS31); see the first citation in ibid, 164-165 $\$ 179$, and further the sixth dynasty texts Urk I 98, 9 (further Strudwick, Texts from the Pyramid Age, 459 (\#256)), Urk I 253, 14 (further ibid, 458 (\#247)), and CG 1574 (where the
Kingdom it serves regularly as such. ${ }^{64}$

Thus, bnti-imn.tiw creates a kind of commutative bond between Osiris and Anubis. The transfer of the term is an indication of the close relations between Osiris and Anubis in this period. ${ }^{65}$ Another is their sharing of the designations 'Lord of the West', 66 'Lord of Abydos', ${ }^{67}$ and 'Lord of the Sacred Land'. ${ }^{68}$

In summary, while in the fourth dynasty only Anubis appears in the divine formula $b$ tp-di-<god $>$, in the fifth all three gods figure into it. At that time Khentimentiu also appears as an epithet to Anubis, but seems to split away from that god, and then is joined with Osiris, and the three share further designations. The relations suggest that these gods were not yet as differentiated as they would later be. Osiris's sphere of significance overlapped that of Anubis, and it is in that context that he is introduced to the divine formula.

The Pyramid Texts show a slightly different story. While the god Osiris is attributed anthropomorphic determinatives in non-royal fifth dynasty texts (beginning with his very first attestation), there is a Pyramid Text which textually identifies him as a jackal, ${ }^{69}$ just as Anubis traditionally and Khentimentiu originally ${ }^{70}$ are. In conformity with the

epithet has the anthropomorphic 'Osirian' determinative), for which see Borchardt, Denkmäler des Alten Reiches II, 54.

64 As in W.M. F. Petrie, Tombs of the Courtiers and Oxyrhynkhos (BSA 37; London 1925), pl. 22, 1; K. Sethe, Aegyptische Lesestücke zum Gebrauch im akademischen Unterricht (Leipzig 1928), 69, 4; 70, 17; 71, 2-5. On the god, see further R. Grieshammer, 'Chontamenti', $L \ddot{A}$ I, 964-965.

65 See citations of their immediate juxtaposition in DuQuesne, Jackal Divinities of Egypt I, $166 \$ 182$, and the discussion in ibid, $389 \$ 503$.

66 Anubis with the epithet $n b$ imn.t(i) $t$ cited in DuQuesne, Jackal Divinities of Egypt I, $167 \$ 183$; Osiris with the same in S. Hassan, Excavations at Gîza III (Cairo 1941), 4; Mariette, Mastabas, 368; Khentimentiu with the same, ibid, 230.

${ }^{67}$ For wsir $n b 3 b \underline{d} w$, see S. Hassan, Excavations at Gîza VI part 3 (Cairo 1950), 209 Fig. 207, and see the citation in BegelsbacherFischer, Untersuchungen zur Götterwelt, 125. For bunti-imn-tiw nb $3 b \underline{d} w$, see the citations in DuQuesne, Jackal Divinities of Egypt I, 163 $\$ 178$; this combination continues to be used in the Middle Kingdom mortuary literature in CT $404 \mathrm{~V} 194 \mathrm{~h}$ and CT $405 \mathrm{~V} 207 \mathrm{i}$.

68 This epithet of Anubis is attributed to Osiris in CG 1424, reference to which is made above, n. 57.

69 For Osiris textually identified as a jackal, see PT $690 \$ 2108 \mathrm{a}$ and Griffiths, Origins of Osiris, 143-144, for his treatment of this statement and two others which less strongly indicate a theriomorphic form; the crucial value of this statement is observed also in DuQuesne, Jackal Divinities of Egypt I, 346. On the deceased in the form of a jackal generally (though not with regard to the passage just cited), see H. Roeder, Mit dem Auge sehen. Studien zur Semantik der Herrschaft in den Toten- und Kulttexten (SAGA 16; Heidelberg 1996), 75-78. 70 J. Wegner, The Mortuary Complex of Senwosret III: A Study of Middle Kingdom State Activity and the Cult of Osiris at Abydos (University of Pennsylvania Ph.D. dissertation 1996), 43-44, shows 
Archaic spellings, Khentimentiu receives the jackal determinative (or specification as Anubis) in one text, ${ }^{71}$ and there are a number of others with Archaic phonetic spellings of his name. ${ }^{72}$ It is also noteworthy that, while Khentimentiu is applied to Anubis as epithet in a number of Pyramid Texts passages, ${ }^{73}$ this does not occur with Osiris himself, though some passages do very strongly associate them. ${ }^{74} \mathrm{It}$ is of further interest that Osiris does not receive the epithet 'Lord of the West' in the Pyramid Texts, nor the more common 'Lord of Busiris', ${ }^{75}$ though outside the pyramids he does. With a rich body of comparative material dealing with the same gods, these details show a slightly different treatment, including obsolescent representations in the Pyramid Texts. This suggests that, at least so far as these gods are concerned, elements of the body of literature from which the Pyramid Texts were drawn are older than our earliest attested appearances of Osiris. Given the fact that the offering list is already attested before Osiris, and that it keys in with Pyramid Texts, this is just what one would have expected. Assuming that the god existed in belief already prior to his first attestation, as just argued, it may perhaps be in part due to issues of decorum that his name does not appear before the fifth dynasty-it was perhaps a question of propriety, a truly sacred name.

At the time when Osiris finally does enter the documentary record, so also do predicative statements in which the non-royal dead identify themselves as Akhs, divine beings. ${ }^{76}$ This is an important point, because one of Osiris's chief identities is as an $3 b .{ }^{77}$ Consider the following passages:

PT 223 \$215b-c: 'O Osiris, Ba who is among the Akhs!'

PT $305 \$ 472 \mathrm{~b}$ : 'The ladder is built by Horus before his father Osiris, when he goes to his Akh'.

PT $365 \$ 623 \mathrm{a}$ : 'for you are an Akh, one whom Nut bore'.

PT 422 \$754c: 'This Akh who is in Nedit comes'.

that Khentimentiu is attested with "Osiris” determinative consisting of a mummified Upper Egyptian king wearing the White Crown and holding the crook and flail' in sixth dynasty non-royal texts. It is possible that this iconography was originally appropriate to Khentimentiu rather than Osiris; see the references in DuQuesne, Jackal Divinities of Egypt I, 168 n. 234.

71 PT $357 \$ 592 \mathrm{~b}$ (MN).

72 bnti-imn-tiw is written with $m n$-gameboard sign in PT $305 \$ 474 \mathrm{c}$ (W), PT $357 \$ 595 b$ (TPM), PT $371 \$ 650$ c (TP), PT $438 \$ 811 \mathrm{a}, \mathrm{d}$ (P), PT 441 \$818b (P), PT $667 \$ 1936 f(\mathrm{Nt})$.

73 PT $81 \$ 57 d$, PT $224 \$ 220$ c, PT $225 \$ 224 b$, PT $419 \$ 745 a, P T$

$650 \$ 1833$ c, and CT 936 VII 138 r.

74 PT $601 \$ 1666 a$, PT $677 \$ 2021$ a.

75 Compare the later incorporation of these epithets in the Middle Kingdom mortuary literature in CT 605 VI 218c (wsir nb imn.t) and CT $434 \mathrm{~V} 285 \mathrm{e}$ (wsir $n b \underline{d} d w$ ).

76 The word $3 b$ is already a designation of deceased persons on Archaic Period seals; see P. Kaplony, Die Inschriften der ägyptischen Frühzeit I (ÄgAbh 8; Wiesbaden 1963), 37.

77 See G. Englund, Akh, une notion religieuse dans l'Égypte pharaonique (Boreas 11; Uppsala 1978), 51-52.
PT 437 \$793b: 'Raise yourself as Osiris, as the Akh, the son of Geb, his first (born)!'

PT 468 \$899a: 'Let Osiris live, let the Akh who is in Nedit live!' PT 479 \$990a: 'O Re, impregnate the belly of Nut with the seed of the Akh who is in her'.

PT 553 \$1354b: 'Osiris has given you Akh-ness'.

PT $556 \$ 1385$ c: 'for this father of mine Osiris Pepy has truly become an Akh'.

PT $637 \$ 1804 a-b$ : 'Be equipped with the form of Osiris, being an Akh thereby more than the Akhs'.

PT 1005 P/S/Se 89-91: 'A[rise to S] eth, a[s Osiris], as the Akh, the son of Geb!'

In the Pyramid Texts, the word $3 b$ is found in about 175 instances, a frequency which helps make it one of the most important concepts in the corpus. Of special interest are declarations that the deceased has become an Akh in the Akhet, the horizon. ${ }^{78}$ This phraseology is a transparent reference to rebirth and resurrection as the sun god in the east. It is an expression of attainment. And because Akh-hood was a goal sought by non-royal persons as well, what is at hand is not a rupture between classes, but a commonality of aspiration.

\section{Means of becoming an Akh: ritual and knowledge}

What may be positively seen is that king and elite both aspired to become an Akh. The connection is of great value, as these aspirations are recorded within the contexts of two different discourses. Transposed from their original contexts, the Pyramid Texts were displayed in sealed-off, subterranean chambers, and there they address the deceased and speak of him in the third person. Meanwhile, the nonroyal statements almost always appear in above-ground accessible areas, ${ }^{79}$ and they are spoken by the deceased himself in addressing a human audience. The Pyramid Texts are texts designed to bring about a particular state, and it is in a ritual context that they make reference to being an Akh. The non-royal texts designate the dead as an Akh, but they are not themselves the instruments of achieving it.

Nevertheless, the non-royal texts do refer to the means by which this state is attained: ritual and knowledge. ${ }^{80}$

\footnotetext{
78 PT $217 \$ 152 d ;$ PT $264 \$ 350$ c; PT $357 \$ 585 a ;$ PT $364 \$ 621 b ;$ PT $368 \$ 636 c ;$ PT $487 \$ 1046 b ;$ PT $532 \$ 1261 b ;$ PT 664B \$1887b. 79 E. Edel, Untersuchungen zur Phraseologie der ägyptischen Inschriften des Alten Reiches (MDAIK 13; Berlin 1944), 30 (\$5, 24). The exceptions are Bebi and Kaiherptah, presented below. The unusual location of Kaiherptah's statements is remarked upon by H. Junker, Gîza VIII (Vienna 1947), 119, and his evaluation is applicable to Bebi also: 'Die Anbringung des Textes in der Sargkammer ist sehr befremdlich und kann wohl nur auf eine Gedankenlosigkeit zurückgeführt werden. Er gehört zu den Anreden an die Besucher des Grabes ... und sollte also von diesen gelesen werden.... Keineswegs aber gehören solche Texte in die unzugänglichen unterirdischen Räume, da sie dort ihren Zweck ganz verfehlten; auf Grabräuber wollte man gewiß keinen Eindruck machen'.

80 On these statements, see Edel, Untersuchungen zur Phraseologie,
} 
a. Knowledge of that by which one becomes an Akh ( $r b$ 3b $n y)$

\section{$T i^{81}$ (fifth dynasty, second half; Saqqara)}

I know everything by which an Akh becomes an Akh who is passed to the necropolis; [I know everything by which he is equipped with the great god]; I know everything by which he ascends to the great god.

\section{$\mathrm{Hezi}^{82}$ (Teti; Saqqara)}

I am an Akh more skilful than any Akh; I am an Akh more equipped than any Akh: I know everything skilful, by which an excellent Akh becomes skilful, and by which an Akh who is in the necropolis becomes an Akh.

\section{Merefnebef ${ }^{83}$ (Userkare/Pepy I; Saqqara)}

And I know everything by which an Akh who is passed to the necropolis as one venerated of the great god by the king becomes an Akh. And I know everything by which he ascends to the great god.

\section{Nekhbu ${ }^{84}$ (Pepy I; Giza)}

I am a skilful Akh: I know everything by which one is an Akh in the necropolis.

\section{Ibi ${ }^{85}$ (Pepy II; Deir el-Gabrawi)}

I am a skilful equipped Akh: I know every secret magic of the Residence, every secret by [which] one becomes an Akh [in] the necropolis.

Idu Seneni ${ }^{86}$ (Pepy II or later; El-Qasr wa es-Saiyad)

25; H. Junker, Pyramidenzeit. Das Wesen der altägyptischen Religion (Zurich 1949), 92; Englund, Akh, 128; E. Edel, 'Inschrift des Jzj aus Saqqara', Z̈̈S 106 (1979) 113; R. J. Demarée, The 3h iqr $n$ Restelae: On Ancestor Worship in Ancient Egypt (Leiden 1983), 193 and 210; Baines, JARCE 26 (1990) 11-12; Silverman, in O'Connor and Silverman (eds), Ancient Egyptian Kingship, 81; Nordh, Aspects, 171; N. Kloth, Die (auto-)biographischen Inschriften des ägyptischen Alten Reiches: Untersuchungen zu Phraseologie und Entwicklung (SAK Beiheft 8; Hamburg 2002), 116-119; Smith, in Dieleman and Wendrich (eds), UCLA Encyclopedia of Egyptology, 3. For similar examples, see E. Doret, The Narrative Verbal System of Old and Middle Egyptian (Geneva 1986), 102-103 with nn 1294 and 1300.

81 Edel, Untersuchungen zur Phraseologie, 66-67.

82 D. P. Silverman, 'The Threat-Formula and Biographical Text in the Tomb of Hezi at Saqqara', JARCE 37 (2000), 5, Fig. 4b.

83 K. Myśliwiec et al., The Tomb of Merefnebef (Saqqara I; Warsaw 2004) 73-74 and pl. 33.

84 Urk I 218, 4-6.

85 Norman de Garis Davies, The Rock Tombs of Deir el Gebrawi I (ASE 11; London 1902), pl. 23. For the improved reading of the text, see Edel, Untersuchungen zur Phraseologie, 23, and correct the reading and translation of N. Kanawati, Deir el-Gebrawi II. The Southern Cliff (ACER 25; Oxford 2007), 54 and pl. 54 accordingly. 86 E. Edel, Hieroglyphische Inschriften des Alten Reiches (Opladen 1981), Fig. 4.
I am a [skilful] and efficacious Akh: I know every secret of hieroglyphs by which one becomes an Akh in the necropolis.

Tjetu I ${ }^{87}$ (late sixth dynasty; Giza)

[I am] a skilful lector priest who knows his utterance, and I know all the skilful magic by which he becomes an Akh in the necropolis.

Shen'ay ${ }^{88}$ (late sixth dynasty; Abydos)

I know all the magic by which one becomes an Akh in the necropolis.

$B e b i^{89}$ (sixth dynasty or later; Giza)

I know everything by which one becomes an Akh in the necropolis.

\section{b. Performance of ritual by which one becomes an Akh} (iri i

Ti (fifth dynasty, second half; Saqqara)

Every worthy ritual by which one becomes an Akh has been performed for me, that which is to be done for a skilful one among the Akhs, by the service of the lector priest; I am initiated [to every worthy rite by which one becomes an Akh].

\section{Nima'atre ${ }^{90}$ (fifth dynasty, second half; Saqqara)}

One whom the king loves is the lector priest who will enter this tomb of mine to perform ritual according to the secret writing of the craft of the lector priest.... The king commanded that every ritual (by) which one becomes an Akh be done for me.

\section{Kaikherptah ${ }^{91}$ (Izezi or later; Giza)}

One whom the king and Anubis loves is the lector priest who will perform for me the rite by which an Akh becomes an Akh according to that secret writing of the craft of the lector priest.

\section{Nihetepptah ${ }^{92}$ (Izezi or later; Saqqara)}

Every worthy ritual (by) which one becomes an Akh has been done for me.

87 W. K. Simpson, Mastabas of the Western Cemetery: Part I (Giza Mastabas 4; Boston 1980), Fig. 15.

88 H. Frankfort, 'The Cemeteries of Abydos: Work of the Season 1925-26', JEA 14 (1928) pl. 20.3.

89 J. Capart, Chambre funéraire de la Sixième Dynastie aux Musées Royaux du Cinquantenaire (Brussels 1906), pl. 5.

90 S. Hassan, Excavations at Gîza II (Cairo 1936), Fig. 231. According to Edel, Untersuchungen zur Phraseologie, 26, the instrumental $n y$ is omitted from the formula.

91 Junker, Gîza VIII, Fig. 56. On the significance of this statement, see further T. DuQuesne, "Effective in Heaven and on Earth." Interpreting Egyptian Religious Practice for Both Worlds', in J. Assmann and M. Bommas (eds), Ägyptische Mysterien? (Munich 2002), 38

92 A. Badawy, The Tomb of Nyhetep-Ptah at Giza and the Tomb of 'Ankhm'ahor at Saqqara (Berkeley 1978), 7, Fig. 13, and pl. 13. 


\section{Ankhmahor ${ }^{93}$ (Teti; Saqqara)}

[O lector priest] who will enter this tomb of mine in order to do the Akh ritual according to that secret writing of the craft of the lector priest, /// /// // his name, and recite for me the equipped $s 3 b \cdot w$.

Mereruka $^{94}$ (Teti; Saqqara)

As reconstructed, this text matches that of Ti given above.

\section{Merefnebef ${ }^{95}$ (Userkare/Pepy I; Saqqara)}

And all the Akh and worthy rituals have been performed for me-Wenis-ankh is his great name ${ }^{96}$ - which are done for the one skilful among] the Akhs by the service of a skilful lector priest who really truly knows the rituals. And I am initiated to the secrets of the great god.

\section{Shen'ay ${ }^{97}$ (late sixth dynasty; Abydos)}

Every ritual by which one becomes an Akh has been performed for me.

Claims of being an Akh by knowledge and ritual begin to appear toward the end of the fifth dynasty and continue through the sixth. Usually the two phrases occur separately. They are optionally included rhetorical flourishes, not components essential to tomb decor. In many cases, the statements are presented as part of a threat, as with Shen'ay, who says to visitors to his tomb:

As for anyone who will take anything of mine by force, I will be judged with them in the necropolis by the great god when they are in the West, and they will be poorly remembered in the necropolis, for I am a skilful Akh: I know all the magic by which one becomes an Akh in the necropolis, and every ritual by which one becomes an Akh has been performed for me.

In order to make the threat persuasive the deceased claims to be an Akh. To support that claim, the deceased indicates that two ways by which that state is attained have been achieved by him. One becomes an Akh by knowledge of arcana and by the performance of ritual.

What is the nature of this knowledge? Idu claims to be an Akh by 'knowing every secret of hieroglyphs', and similarly Ibi, whose status as an Akh is due to his knowledge of 'the secret magic of the Residence', the capital itself. It is not a question of drawing a parallel between two different forms of knowledge, court secrets on the one hand and non-royal knowledge for the afterworld on the other. It is

\footnotetext{
93 Urk I 202, 15-18, or any of the more recent publications of this monument listed in Strudwick, Texts from the Pyramid Age, 455 (\#196).

94 See Edel, Untersuchungen zur Phraseologie, 59-61, 66-67, and The Sakkarah Expedition, The Mastaba of Mereruka. Part II (Chicago 1938), pl. 213.

95 Myśliwiec et al., The Tomb of Merefnebef, 72-73 and pl. 33.

96 This statement is an interpolation (loc. cit., n. 38).

${ }_{97}$ Frankfort, JEA 14 (1928) pl. 20.3.
}

to know the sacred arcana of the royal circle itself; it is to know hieroglyphic texts. ${ }^{98}$

The phraseology is subject to substantial embroidery, as with the claims of Ti:

[for I am a skilful Akh] /// /////////////: every worthy ritual (by) which one becomes an Akh has been performed for me... I am initiated [to every worthy rite by which one becomes an Akh]; I know everything by which an Akh becomes an Akh who is passed to the necropolis; [I know everything by which he is equipped with the great god]; I know everything by which he ascends to the great god; I know everything by which he is worthy with the god.

He mentions the routes of ritual and knowledge, and expands the basic formulae. The rituals have been performed, Ti knows everything needed to become an Akh, and he knows how to ascend to the great god. The last statement offers a palpable link to an inscription to which David P. Silverman and others have drawn attention. ${ }^{99}$ The owner of the inscription, Sabni, is an Akh because of his knowledge of a text of ascending. He says, 'I know the utterance of ascending to the great god, lord of the sky'. ${ }^{100}$ The fusion of Akh, knowledge, ascent, and sky make the passage unequivocal: the deceased claims to know a text by which one can literally get into heaven.

As Mathieu has pointed out, ${ }^{101}$ the kind of text mentioned by Sabni is semantically parallel to one mentioned in the Pyramid Texts. Priests in the process of purifying the deceased are said to perform for him the the utterance of ascent for Pepy, for life and dominion, that Pepy might ascend to the sky' (PT $254 \$ 281 \mathrm{~b}$ ). The passage makes it clear that the performance of such a text is a means of getting to the sky. In another Pyramid Text the goal is also the sky, and it is reached through knowledge of texts and magic:

May you stride the sky at your striding, and travel the North and the South in your travelling! As for the one who truly knows it, this utterance of Re, and performs it, this magic of Harakhti, he will be one known of Re; he will be a companion

of Harakhti. Neferkare knows it, this utterance of Re, with Neferkare performing this magic of Harakhti: Neferkare is one known of Re, and Neferkare is a companion of Harakhti, with the hand of Neferkare grasped at the sky among the Followers of Re. (PT 456 \$854-856)

The asseveration is generic: the one with access to the sky is the one who has technical knowledge. It is not the king alone, nor one who has physical possession of a text

\footnotetext{
98 cf Smith, in Dieleman and Wendrich (eds), UCLA Encyclopedia of Egyptology, 7.

99 Jürgens, Grundlinien, 86; Silverman, in O'Connor and Silverman (eds), Ancient Egyptian Kingship, 81-82; Nordh, Aspects, 171; and Mathieu, in Bickel and Mathieu (eds), D'un monde à l'autre, 257. ${ }^{100}$ L. Habachi, Sixteen Studies on Lower Nubia (Cairo 1981), 21 Fig. 5. 101 Mathieu, in Bickel and Mathieu (eds), D'un monde à l'autre, 257.
} 


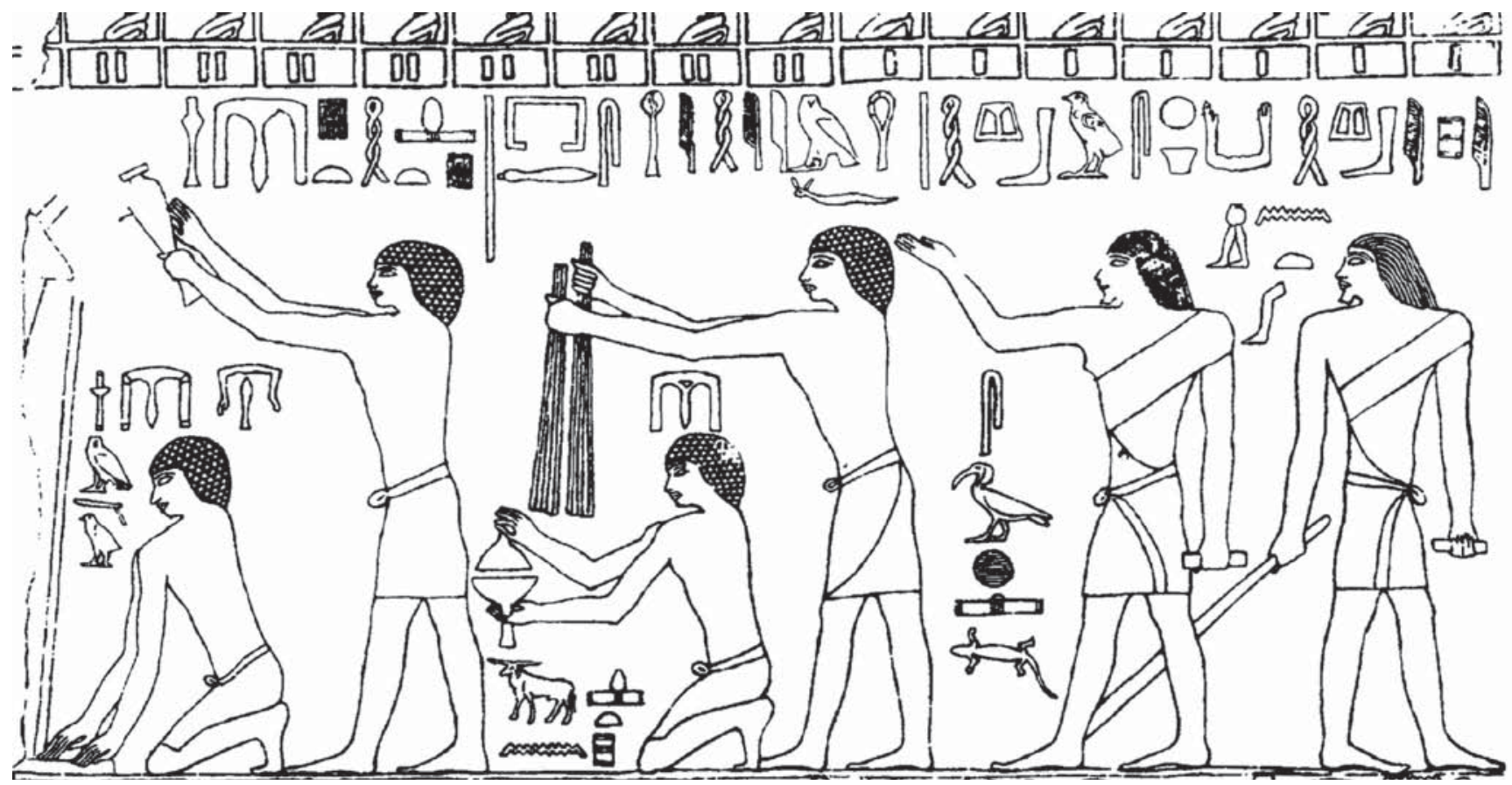

Fig. 1: Ritualists under Offering List, after Harpur and Scremin, Ptahhotep, 365

in his tomb; it is not social stature which opens the earth, and it is not a physical text. Knowledge was the condition of access. Hence yet another Pyramid Texts passage declares, 'He has opened the earth through what he knows' (PT 254 $\$ 281 b$ ). The hieroglyphs of the Pyramid Texts represent the object of knowledge, which is deployed in ritual to escape from the tomb and ascend to the sky.

The Pyramid Texts also speak of the efficacy of ritual in attaining the desired afterlife state. It is brought about by the performance of ritual, as in PT 77. In it, a priest addresses oil while applying it to the deceased, telling it that it is the means by which one becomes an Akh:

$\mathrm{O}$ oil, oil, where were you? $\mathrm{O}$ that which is in the brow of Horus, where were you? In <the brow> of Horus you were; in the brow of Unas do I put you, that you give pleasure to him through your influence, that you make him an Akh through your influence. (PT $77 \$ 52$ )

The deceased is frequently informed that what is important is the ritualised, vocal performance of priests: 'The land speaks: the doors of Aker open to you; the doors of Geb spread open to you, and you go forth at the voice of Anubis, when he as Thoth makes you an Akh' (PT 437 $\$ 796) .{ }^{102}$ Because priests speak in the role of gods, they are able to make the deceased into an Akh. ${ }^{103}$ The common denominator to the application of oil and vocal performance

102 Similarly PT 483, PT 610, PT 666, and PT 734.

${ }^{103}$ H. M. Hays, 'Between Identity and Agency in Ancient Egyptian Ritual', in R. Nyord and A. Kyølby (eds), Being in Ancient Egypt: Thoughts on Agency, Materiality and Cognition (Oxford 2009), 26-30. is recitation, for even the application of oil is accompanied by words. It is the power of the word to attribute meaning that makes the physical deed sacred and efficacious. ${ }^{104}$ The state of being an Akh is induced by ritual.

In the non-royal texts the knowledge and rituals by which one becomes an Akh are not given; they are only laid claim to. The Pyramid Texts, on the other hand, constitute these very things. The non-royal deceased lays claim to knowledge and ritual as supports to exhortations to the living, as when backing up a threat or encouraging the performance of ritual for him. He does not present this knowledge or the ritual scripts as the Pyramid Texts do, but this is because of a difference in the nature of the two discourses. And yet despite fundamental differences in discursive structure, both indicate a harmony of means and end between king and courtier.

\section{6. ssh.w, Pyramid Texts, and pictorial representations of mortuary service ${ }^{105}$}

Given the fact that both forms of discourse express a

\footnotetext{
${ }^{104}$ For the concept of sakramentale Ausdeutung, see J. Assmann, 'Die Verborgenheit des Mythos in Ägypten', GM 25 (1977) 15-25, id., 'Semiosis and Interpretation in Ancient Egyptian Ritual', in S. Biderman and B.-A. Scharfstein (eds), Interpretation in Religion (Leiden 1992), 87-89, and 105-106, and id., 'Altägyptische Kultkommentare', in J. Assmann and B. Gladigow (eds), Text und Kommentar. Archäologie der literarischen Kommunikation IV (Munich 1995), 97-99.

105 The following discussion is based on my presentation 'Representations of Mortuary Ritual from the Old to the New Kingdoms',
} 
common goal, and since some of the non-royal statements even make reference to secret texts as substrate for attainment, there are tangible grounds to suppose that the knowledge and rituals were common to king and noble alike. The textual basis for this body of knowledge and its ritual scripts constitute a discursive formation of Old Kingdom mortuary literature, only partially preserved to us in copies found in royal tombs. Kaiherptah appeals to 'the lector priest who will perform for me the rite by which an Akh becomes an Akh according to that secret writing of the craft of the lector priest'. Rites-literally ib.t 'things'-are to be done according to secret writings, the technique of the lector priest. Secrecy was bound up with activities requiring technical knowledge, and therefore Anubis was the hry-šsts par excellence. ${ }^{106}$ His was the ultimate knowledge, the goal of which was to ensure resurrection.

Laurent Coulon concludes that the secret writings and craft of the lector priest must constitute s3h.w. 'Akh-makers', recitations without structural difference with the inscriptions in the royal pyramids. ${ }^{107}$ The connection he makes is inevitable. Pictorial representations of mortuary service become stereotyped in the Old Kingdom, to include the royal and non-royal deceased at offering table, offering list, and priests performing rites. Normally, one of the papyrusbearing priests will receive the caption $s 3 h \cdot t$ ' making into an Akh', or, as in Fig. 1, ssb. w '3s. w' (reciting) numerous ssh.w'.

The connection made by Coulon is resonant of Sethe's later modulation of his opinion of the religious history of the Old Kingdom. Although Sethe may be deemed as one of the joint authors of the democratisation theory, some twenty years after the publication of the first volume of his Pyramidentexte he asserted that, even though one does not find a proper body of non-royal mortuary texts for centuries, the existence of the same is indirectly attested by Old Kingdom pictorial representations of ritual performances in accessible cult chambers. Such scenes show a lector priest reciting $s 3 b \cdot w$ with a papyrus roll in hand, just as one sees in Fig. 1, and according to Sethe ssh.w was actually the technical term for mortuary literature in general. ${ }^{108}$ The conclusion is inevitable, because the term is

given at the 53rd Annual Meeting of the American Research Center in Egypt, held at the Johns Hopkins University in 2002.

106 Thus already in the Old Kingdom the hieroglyph of the jackal-god alone could represent this title; see the discussion of R. Ritner, The Mechanics of Ancient Egyptian Magical Practice (SAOC 54; Chicago 1993), 231-232. On the association of Anubis with this title, see the references cited in DuQuesne, in Assmann and Bommas (eds), Agyptische Mysterien?, 39 n. 25.

${ }^{10^{-}}$L. Coulon, 'Rhétorique et stratégies du discours dans les formules funéraires: les innovations des Textes des Sarcophages', in S. Bickel, B. Mathieu (eds), D'un monde à l'autre, 121-122; similarly Willems, in Assmann and Roeder (eds), Handbuch der altägyptischen Religion. ${ }^{108}$ K. Sethe, 'Die Totenliteratur der Alten Ägypter: Die Geschichte einer Sitte', Sitzungsberichten der preussischen Akademie der Wissenschaften
Table 1: Pyramid and Coffin Texts entitled as $s 3 h \cdot w$

$\begin{array}{ll}\text { Text } & \text { Source } \\ \text { PT 77 } & \text { Sq18X } \\ \text { PT } 81 & \text { Sq18X } \\ \text { PT 213 } & \text { M1C } \\ \text { PT 214 } & \text { L-A1 } \\ \text { PT 220 } & \text { Sed1Cop, L-A1 } \\ \text { PT 422 } & \text { Sq18X } \\ & \\ \text { CT 1 } & \text { MC105 } \\ \text { CT 7 } & \text { MC105 } \\ \text { CT 63 } & \text { TT 353 (NK) } \\ \text { CT 66 } & \text { B10C } \\ \text { CT 73 } & \text { B10C } \\ \text { CT 74 } & \text { Sq3C and T2C } \\ \text { CT 335 } & \text { BH1Br } \\ \text { CT } 842 & \text { T2C }\end{array}$

applied to Pyramid and Coffin Texts with some regularity in the Middle Kingdom. Since the attainment of the state of being an Akh is a chief goal of the Pyramid Texts, and as the meaning of the term s3b is 'to make into an Akh', it may be said that the title $s 3 h \cdot w$ indicates the purpose of the whole body of mortuary literature. ${ }^{109}$ Its texts were intended to make the deceased into an Akh. Table 1 lists the ones specifically designated as such.

Significantly, two texts to receive the title are PT 77 and 81 , for presenting cloth and oil. ${ }^{110}$ These two are from the offering ritual, and from the very same set of ritual actions and recitations that match the offering list. The facts coalesce as follows: 1) PT 77 and 81 are called ssh.w in the Middle Kingdom, 2) PT 77 and 81 correspond to two items of the offering list, and 3) the lector priest beside the offering list often receives the caption 'Many ssb. w' or 'Making into an Akh'. These are not ruptures between social classes. What the evidence shows are continuities between multiple dimensions of evidence. This is the simplest conclusion: the $s 3 h \cdot w$ given in the hieroglyphs of the Pyramid Texts constitute the words of the rites pictorially shown performed for elite persons.

The democratisation theory really is obsolete. Non-royal persons claimed to attain the status of Akh-hood in the Old

Phil.-Hist. Klasse 1931 XVIII (Berlin 1931), 522-523; see also 529. Even so, he continued to maintain that the adoption of the Pyramid Texts by non-royal persons was a symptom of the collapse of the state at the end of the Old Kingdom, as with their assumption of the form of Osiris; ibid, 527-528.

109 cf Hays, JEOL 41 (2009) 53-54, and Eyre, The Cannibal Hymn, 64-69.

110) Texts in the tomb of Ihy (Sq18X), for which see C.M. Firth and B. Gunn, Teti Pyramid Cemeteries I (Cairo 1926) 287; for further reference to this tomb, see Willems, Chests, 32. 


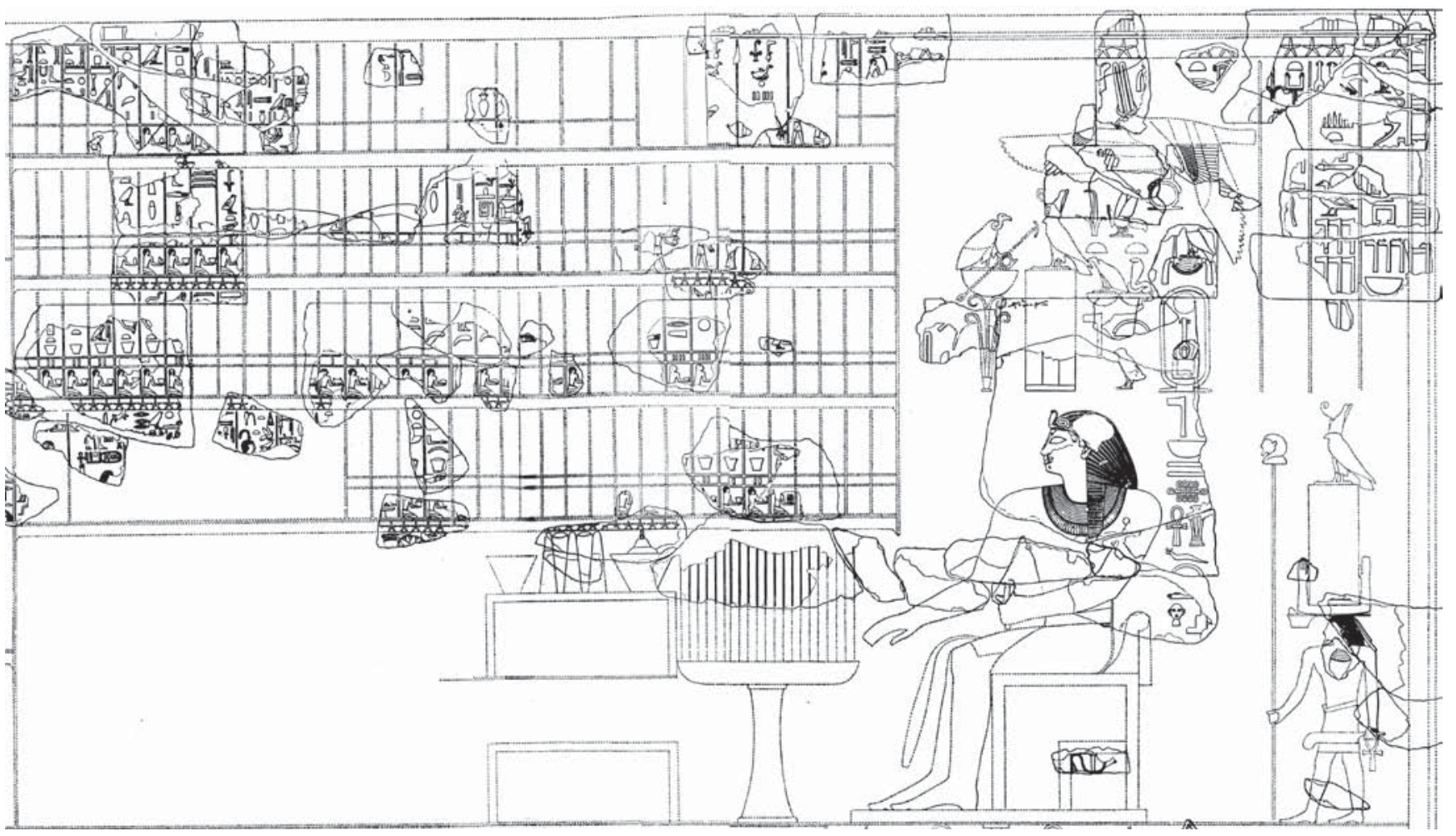

Fig. 2: Mortuary Service for Pepy II, G. Jéquier Le monument funéraire de Pepi II, II (Cairo 1938), pl.61

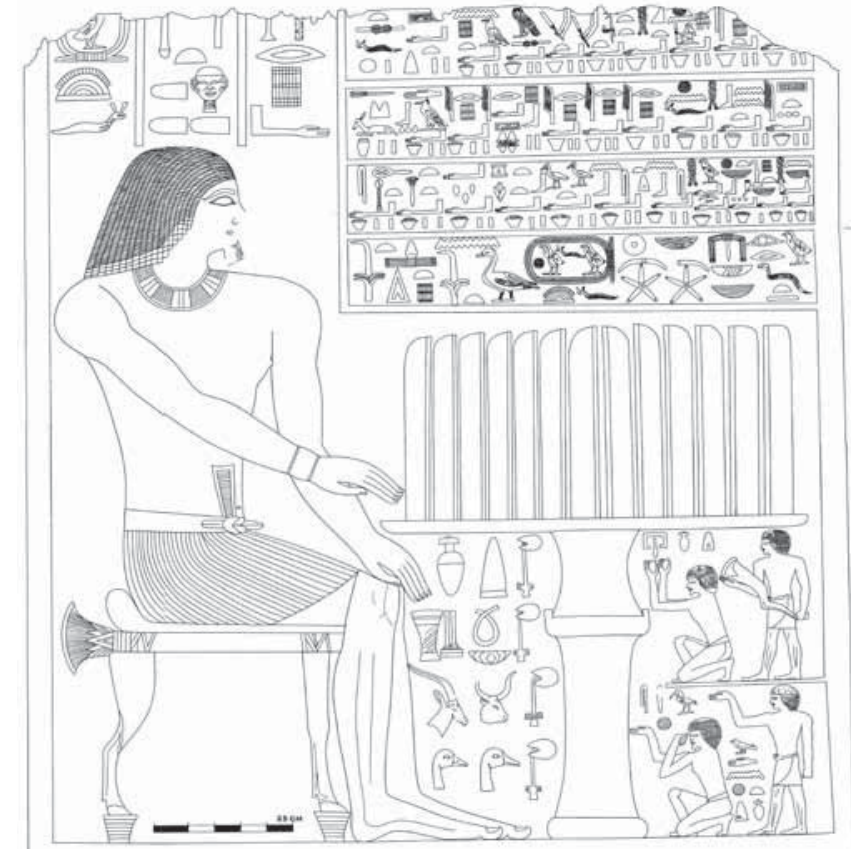

Fig. 3: Nascent Type A Offering List. Simpson, Kawab, Khafkhufu I and II, Fig. 32
Kingdom, and that is the purpose of the Pyramid Texts. Non-royal persons claimed to attain this status by ritual and knowledge, and that is what the Pyramid Texts embody. Non-royal persons are represented as the object of the offering ritual, and it is keyed in with ninety Pyramid Texts. The captions accompanying representations of mortuary ritual for non-royal persons state that they are being made into an Akh or that $s 3 h \cdot w$ are being performed for them, and the term $s 3 b \cdot w$ is a title for texts of the mortuary literature, including Pyramid Texts. These are continuities of religious belief and practice.

Continuities in representation of mortuary cult for both royal and non-royal dead extend from the Old Kingdom to the New Kingdom and beyond. Since the beginning of the fifth dynasty, mortuary service representations contain three stereotyped elements: ritualists, offering list, and deceased at offering table. ${ }^{111}$ Most remarkable about this pattern is that surviving fragments of decoration from the sanctuaries of pyramid temples contain precisely these components. At the right of Fig. 2, the deceased Pepy II is shown seated at the offering table, the offering list in front of him, and ritualists next to that. ${ }^{12}$ They do for the king the same kinds of things as are done for the non-royal Ptahhotep, and for dozens of other members of the elite. The same gestures,

\footnotetext{
111 cf Barta, Die altägyptische Opferliste, 7.

112 On this scene, see further G. Lapp, Die Opferformel des Alten Reiches (Mainz am Rhein 1986), 186.
} 
the same ritual poses - all pictorially amplifying the meaning of the offering list. The actions ritually done for the king are the same as the actions ritually done for the elite.

And these are traditional acts. After the Old Kingdom, the king is the beneficiary of the same activities, as for Queen Hatshepsut in the eighteenth dynasty temple at Deir el-Bahari. ${ }^{113}$ There the ritualists are integrated into a scene that was already stereotypical for centuries, and in her case the representation is even more forthright: utterances found in the Pyramid Texts are integrated into the offering list and combined with utterances found in the Coffin Texts. A contemporary of Queen Hatshepsut is the official Puyemre. He displays essentially the same stereotypical scene, down to the overt inclusion of texts. ${ }^{114}$ Deceased at offering table, offering list, and ritualists are the standard elements of mortuary service representations in the Middle Kingdom as well, as in the tomb of Amenemhat, an official contemporary with Senwosret I. ${ }^{115}$ From the offering chapel of his king's pyramid temple, precisely the same sort of representation may be reconstructed, including the three stereotypical elements. ${ }^{116}$ Returning to the Old Kingdom, before Pepy II, one finds fragments of the offering list with Sahure and other fifth dynasty kings. ${ }^{117}$ But Sahure's fragments are not the earliest elements of this kind of list. They appear in canonical composition and order already at the very beginning of the fifth dynasty in the tomb of the non-royal person Debeheni. ${ }^{118} \mathrm{His}$ is the earliest attested

113 E. Naville, The Temple of Deir el Bahri. Part IV (EEF 19; London 1900), pl. 110.

${ }^{114}$ Norman de Garis Davies, The Tomb of Puyemrê at Thebes II (RPTMS 3; New York 1923), pls 49-50.

115 P.E. Newberry, Beni Hasan. Part I (ASE 5; London 1893), pl. 17. On Middle and New Kingdom scenes of mortuary service, see J. Spiegel, 'Die Entwicklung der Opferszenen in den Thebanischen Gräbern', MDAIK 14 (1956) 190-207.

116 Di. Arnold, The Pyramid of Senwosret I (PMMA 22; New York 1988), pl. 56.

117 See the references given above in n. 38 .

118 See Lapp, Opferformel, 147 Fig. 26 (< LD II pl. 35), and/or S. Hassan, Excavations at Gîza. IV. 1932-1933 (Cairo 1943), 176 fig. 122. The correct date of Debeheni's tomb is 'end of fourth dynasty to early fifth dynasty'; the reasons are given in Barta, Die altägyptische Opferliste, 47. Kloth, Die (auto-) biographischen Inschriften, 38-39, attempted to push Debeheni's date to the middle of the fifth dynasty in saying, 'Die Inschrift berichtet von der Errichtung des Grabes durch Mykerinos, und folglich wurde auch der (auto-)biographische Text selbst an das Ende der 4. Dyn. datiert. Mehrere Argumente sprechen jedoch für eine Datierung nicht vor die Mitte der 5. Dyn.'. But to be precise only one of the points thereafter advanced by her can speak for such a date. And it does so weakly, since it is merely involves the comparative dating of a type of decoration found in Debeheni's tomb. Observing that scenes from the 'Butic burial' occur in Debeheni, Kloth asserts that they are not attested before the second half of the fifth dynasty. But that is only true if Debeheni's decoration was not executed before this time. In other words, the dating of the advent of

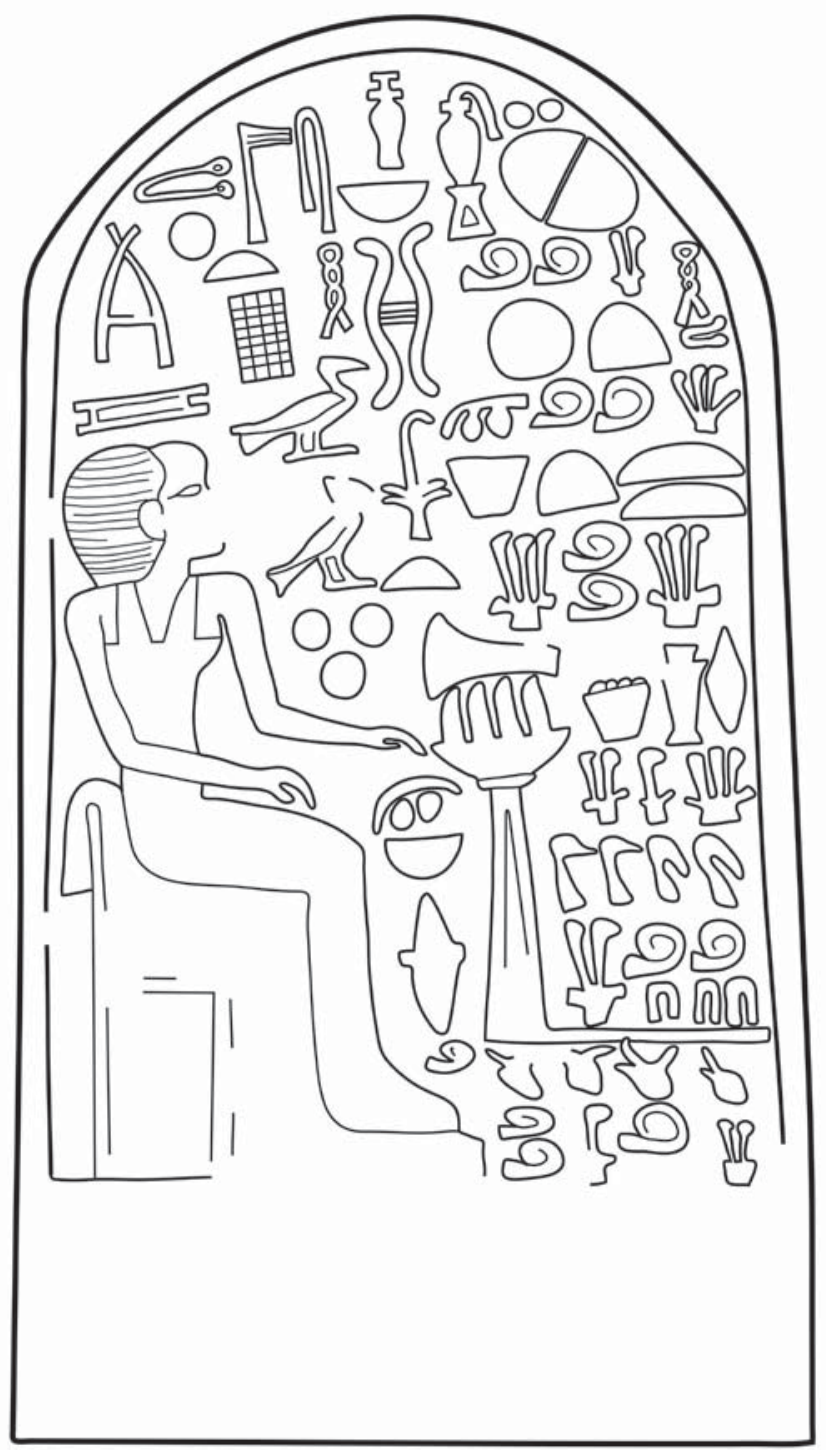

Fig. 4: Bankfield Stele. Author's drawing after Gardiner JEA 4 (1917), pl. 55

Type A offering list with ninety matches to the offering ritual Pyramid Texts of the pyramid of Unas. But precursors to this list appear already in the middle of the fourth dynasty, when nearly all of the elements of offering lists from the tomb of Khafkhufu are found to match those of Debeheni's canonical form, though not yet in canonical order (Fig. 3).

Scholars including Hermann Junker, Winfried Barta and James P. Allen have noticed the interlocking connections between the canonical offering list and the offering ritual Pyramid Texts and have concluded that the latter give the recitations for the rites specified in the former. ${ }^{119}$ And as

a type of decoration is dependent on the date of the tombs bearing it, not the reverse.

119 See above, n. 38. 
this offering list is first attested in the tomb of the non-royal personage Debeheni at the beginning of the fifth dynasty and unmistakable elements of it are already found in a non-royal tomb securely dated to the reign of Khufu, ${ }^{120}$ it is crucial to observe that it begins to emerge over two centuries before Unas. When did 'democratisation' take place? If there ever was such a thing, it must have taken place as early as Khufu's time.

In fact, the elements of the stereotyped scenes of mortuary service already begin to appear as early as the second dynasty with one of the earliest representations of the 'Speisetischszene' (Fig. 4). A stele once in the Bankfield Museum, ${ }^{121}$ now lost, shows a king's daughter ${ }^{122}$ seated at an offering table, and above her appear perhaps the earliest attestations of the Egyptian rites of censing and libating.

Turning the clock back even further, one may discern in the foetal posture of the buried non-royal dead indications

${ }^{120}$ For the date, see Simpson, The Mastabas of Kawab, Khafkhufu I and II, 9 with n. 2.

${ }^{121}$ For this object, see A. H. Gardiner, 'An Archaic Funerary Stele', JEA 4 (1917), 256-260. According to the personal communication of Richard Macfarlane, Collections Manager, Bankfield Museum, on 13 April 2010, it is now lost. To its bibliography in PM VIII part 3, 1-2 (803-002-400), add H. G. Fischer, Egyptian Studies III. Varia Nova (New York 1996), 112-113; W.A. Ward, 'Notes on Egyptian Group-Writing', JNES 16 (1957) 198; W. Helck, 'Zu den theophoren Eigennamen des Alten Reiches', ZÄS 79 (1954) 27 n. 3; Reisner, in Studies Presented to F. Ll. Griffith, 328; A. Scharff, 'Eine archaische Grabplatte des Berliner Museums und die Entwicklung der Grabplatten im frühen Alten Reich', in Studies Presented to F. Ll. Griffith, 355; Junker, Gìza I, 27; and A. Rusch, 'Die Entwicklung der Grabsteinformen im Alten Reich', Z̈̈S 58 (1923) 104. Gardiner, JEA 4 (1917) dates the Bankfield Stele to the second dynasty and is almost universally followed in this regard. Exceptionally the stele is dated to the second or early third dynasty, as by W.S. Smith, $A$ History of Egyptian Sculpture and Painting in the Old Kingdom (New York 1978), 139 and 142-143; and Rusch, Z̈̈S 58 (1923) 104 n. 7 , or even more exceptionally to the third or early fourth dynasty by G.A. Reisner, 'The Position of Early Grave Stelae', in Studies Presented to F. Ll. Griffith (London 1932), 328. The drawing of Fig. 5 is my tracing of Gardiner's photograph, collated against a more recent photo kindly provided by Mr Macfarlane, and collated against drawings of Fischer, Egyptian Studies III, 113 Fig. 2.a and S. Hassan, Excavations at Gîza V (Cairo 1944), 87 Fig. 13. Fischer's drawing certainly and Hassan's probably were made from Gardiner's photo without reference to the original.

122 According to Kaplony, Inschriften der ägyptischen Frühzeit I, 602, the owner's name is bww-i3b.ti, but the traces of the attacked bird's head better suit a rbi.t-bird rather than an $3 b$. On the other hand, he offers parallels to suggest that the name of the mother and not the owner is $m r i(\cdot t)-n \cdot t-p t h$ (or - htp as the case may be). of a belief in the afterlife in the first dynasty. As Christiana Köhler supposes, the posture suggests an intent to be reborn from the womb of the grave $e^{123}$-just as is found in the much later written sources of the Pyramid Texts, when the deceased is reborn from the sky-goddess, who is embodied in the tomb. ${ }^{124}$

\section{Conclusion}

According to the written sources, access to a beatified afterlife was not dependent on the possession of texts on one's tomb walls. It was dependent on knowledge and ritual, both of which in the Egyptian world are epitomised in the language of recitation. Access to a desirable afterworld was dependent on these two features, and therefore it was necessarily linked to education and economic power, both of which were conditioned by the king's mighty command.

The Pyramid Texts are a profoundly important manifestation of a wider body of mortuary literature that transcended the bounds of what has survived. Texts of this literature were also copied on perishable furniture and papyri, virtually all of which are lost. More than one social stratum contributed textual content to the Old Kingdom mortuary literature. Among the Pyramid Texts there were surely texts originally composed for non-royal persons. Their inclusion in the Pyramid Texts indicates that social categories of origin were not restrictive, but that texts were transported across social boundaries by adoption.

As is vividly brought home by the shared manner of pictorially representing the same stereotypical scenes of mortuary service, there was a common fund of rites equally valid for king and elite, and there is concrete evidence of their use for non-royal persons already in the fourth dynasty. Along with this, the fact that non-royal persons label certain kinds of texts as s3 $h \cdot w$ in the Middle Kingdom gives one tangible basis to propose that the $s 3 h \cdot w$ shown performed in Old Kingdom elite tombs were precisely texts from the mortuary literature of which the Pyramid Texts formed part. These same rites were those that made the deceased into an Akh. Upon their performance and through their knowledge, the dead were supposed to attain to an exalted state.

Not so the theory of the democratisation of the afterlife.

${ }^{123}$ E. C. Köhler, 'Ursprung einer langen Tradition. Grab und Totenkult in der Frühzeit', in Guksch, Hofmann and Bommas (eds), Grab und Totenkult, 16.

${ }^{124}$ H. M. Hays, 'Unreading the Pyramids', BIFAO 109 (2009), 197. 


\title{
OLD KINGDOM, NEW PERSPECTIVES \\ Egyptian Art and Archaeology 2750-2150 BC
}

\author{
edited by \\ Nigel Strudwick and Helen Strudwick
}

OXBOW BOOKS

Oxford and Oakville 